\title{
High Performance of Power Cables Using Nanocomposites Insulation Materials
}

\author{
A. Thabet ${ }^{1}$, M. Fouad ${ }^{2}$, Abdel-Moamen M. A $^{3}$ and A. El-Nobi ${ }^{4}$ \\ ${ }^{1}$ College of Engineering, Qassim University, Electrical Engineering Department, Buraydah, KSA, \\ ${ }^{1,3,4}$ Nanotechnology Research Center, Faculty of Energy Engineering, Aswan University, Egypt, \\ ${ }^{2}$ Hydro Power Plant Generation Company, Nag Hammadi Hydro Power Plant, Qena, Egypt,
}

\begin{tabular}{|c|c|}
\hline Article Info & ABSTRACT \\
\hline $\begin{array}{l}\text { Article history: } \\
\text { Received Nov 1, } 2019 \\
\text { Revised Jan 2, 2021 } \\
\text { Accepted Jan 12, } 2021 \\
\text { Keyword: } \\
\text { Void } \\
\text { PVC } \\
\text { Finite element method } \\
\text { Nano composites materials }\end{array}$ & $\begin{array}{l}\text { Partial discharges occur the biggest failure problem in power cable insulation } \\
\text { due to distortion of electrical stress. In this paper, it has been investigated on } \\
\text { the effect of spherical nanoparticles of Barium titanate }\left(\mathrm{BaTiO}_{3}\right) \text { and Clay for } \\
\text { enhancing electrostatic field distribution in single and three-core power cables. } \\
\text { It has been applied new strategies of nanotechnology techniques for designing } \\
\text { innovative polyvinyl chloride insulation materials by using nanocomposites } \\
\text { and multi-nanocomposites. Moreover, it has been studied the electrostatic field } \\
\text { distribution within power cable nanocomposites insulation in presence of air } \\
\text { voids, water voids and cupper impurity voids. The electrostatic field } \\
\text { distribution in power cable insulation has been calculated by finite element } \\
\text { method (FEM). A comparative study has been investigated on the effect of } \\
\text { nanocomposite insulation for enhancing electric field stress in power cables. }\end{array}$ \\
\hline & $\begin{array}{r}\text { Copyright }(2021 \text { Institute of Advanced Engineering and Science. } \\
\text { All rights reserved. }\end{array}$ \\
\hline \multicolumn{2}{|l|}{ Corresponding Author: } \\
\hline \multicolumn{2}{|c|}{$\begin{array}{l}\text { Mohamed Fouad, } \\
\text { Nag Hammadi Hydro Power Plant, } \\
\text { Hydro Power Plant Generation Company, } \\
\text { Nag Hammadi, Qena, Egypt. } \\
\text { Email: fouad1284@gmail.com }\end{array}$} \\
\hline
\end{tabular}

\section{INTRODUCTION}

In a power cable, insulation strength of materials has serious role in long time function. In high voltage equipment, local electric field will rise due to humidity, impurity and water, and therefore it leads to increasing electric field. Absorbed water which maybe happens during manufacture process or service period, can cause a major problem and can lead to decrease in cable insulator life time. In polyvinyl chloride cables, existence of electric field with high frequency, water and other electric tensions, can be led to water tree phenomena inside cables and then electric field intensity will increase and results in partial discharge in water location [1]. Partial discharge occurs in places which their electric field intensity is higher than accepted value of insulator in a power cable, Nowadays, Finite Element Method (FEM) has been used to study bubbles effect in high voltage power cable insulations as a basic method. The Finite Element Method can be easily used to calculate the maximum stress inside the void [2]. This finally leads to exact evaluation of electric field distribution in cable insulation system. By using 2-dimension Maxwell software, it is possible to calculate electric field values in each boundary and zone [3]. With the calculation of the magnitude of the electric field intensity and its spatial distribution within the cable, it is possible to set a limit on the voltage rating for a given insulation thickness, or alternatively [4]. The main dissolution products were found to be hydrogen, carbon monoxide, methane and carbon dioxide which are produced in a power cable when exposed to PD activity [5]. In recent years, the progress of nanotechnology science is fast for innovate new insulation materials that have advanced physical and electrical properties [6-18]. It has been studied the electric field calculation in insulation of power cables around conductor and partial discharges in insulation [19-24]. There is a big deal of opportunity to make up the properties of the resulting material to specific applications. From the viewpoint of insulating systems most 
of the activity has been on inorganic oxides (particularly $\mathrm{Fe}_{2} \mathrm{O}_{3}, \mathrm{Al}_{2} \mathrm{O}_{3}, \mathrm{MgO}$ andTiO 2 ) [25]. The aim of this paper is enhancing performance of single and three-core belted power cable that is exposed to manufacture defects like voids, metal impurities. Thus, it has been studied the electrostatic field distribution inside traditional and nanocomposites insulation of power cables in presence of different air void, water void and cupper impurity void. In this study, the importance of using individual and multiple nanoparticles techniques have been tabulated for electrostatic field distribution inside nanocomposites and multiple nanocomposites insulation respectively.

\section{MATHEMATICAL MODEL}

Electric field calculation requires solution of Laplace and Poisson equations. In Past studies, electric field is defined as a source of corona around conductor imperfect partial discharge and early insulation failure. by assuming there is no free surface change at the insulation surface and void boundary, Internal and External electric field of cylindrical void is calculated by following equations [5],[19],[20].

$$
\begin{array}{ll}
E(r)=E_{\circ}\left(i_{r}\left\{1+\left(\frac{\varepsilon_{r}-\varepsilon_{o}}{\varepsilon_{\mathrm{r}}+\varepsilon_{\mathrm{o}}}\right) \times \frac{\mathrm{r}^{2}{ }_{\mathrm{v}}}{\mathrm{r}^{2}}\right\} \cos \theta-i \theta\left\{1+\left(\frac{\varepsilon_{\mathrm{r}}-\varepsilon_{\mathrm{o}}}{\varepsilon_{\mathrm{r}}+\varepsilon_{\mathrm{o}}}\right) \times \frac{\mathrm{r}^{2} \mathrm{v}}{\mathrm{r}^{2}}\right\} \sin \theta\right) \quad \text { for }\left(r>\mathrm{r}_{\mathrm{v}}\right) \\
\mathrm{E}(\mathrm{r})=\mathrm{E}_{\mathrm{o}}\left(\frac{2 \varepsilon_{\mathrm{o}}}{\varepsilon_{\mathrm{r}}+\varepsilon_{\mathrm{o}}}\right)\left(\mathrm{i}_{\mathrm{r}} \cos \theta-i \theta \sin \theta\right) & \text { for }\left(0 \leq \mathrm{r}<\mathrm{r}_{\mathrm{v}}\right)
\end{array}
$$

Internal and External electric field of spherical void is calculated by following equations, [5],[19],[20].

$$
\begin{array}{ll}
E(r)=E_{o}\left(i_{r}\left\{-1-\left(\frac{\varepsilon_{r}-\varepsilon_{o}}{\varepsilon_{\mathrm{r}}+2 \varepsilon_{\mathrm{o}}}\right) \times \frac{\mathrm{r}^{3} \mathrm{v}}{\mathrm{r}^{3}}\right\} \cos \theta+i \theta\left\{1-\left(\frac{\varepsilon_{\mathrm{r}}-\varepsilon_{\mathrm{o}}}{\varepsilon_{\mathrm{r}}+2 \varepsilon_{\mathrm{o}}}\right) \times \frac{\mathrm{r}^{3}{ }_{\mathrm{v}}}{\mathrm{r}^{3}}\right\}\right. & \sin \theta) \quad \text { for }\left(r>\mathrm{r}_{\mathrm{v}}\right) \\
\mathrm{E}(\mathrm{r})=\mathrm{E}_{\mathrm{o}}\left\{-\left(\frac{3 \varepsilon_{\mathrm{o}}}{\varepsilon_{\mathrm{r}}+2 \varepsilon_{\mathrm{o}}}\right)\right\}\left(\mathrm{i}_{\mathrm{r}} \cos \theta-\mathrm{i} \theta \sin \theta\right) & \text { for }\left(0 \leq \mathrm{r}<\mathrm{r}_{\mathrm{v}}\right)
\end{array}
$$

Where, $r_{v}$ is radius of void, $r$ distance from void center, $E_{o}$ uniform dielectric field, $i_{r}$ and $i_{\ominus}$ are unit vectors of the co-ordinate system in the insulation, $\varepsilon_{\mathrm{r}}$ is the permittivity of insulation, $\varepsilon_{\mathrm{o}}$ is the permittivity of air void. All the times irregular problem geometry for void is so complicated that analytical solution is so hard, therefore, researches tried to find new calculating methods to obtain electric field. FEM is chosen for computation use. Electric field equations solution by this method is based on Maxwell equations with boundary conditions. The effective dielectric constant of the inclusion and interphase could be expressed for individual nanocomposite model that contains an interphase region according to [9]- [12] as

$\varepsilon_{\mathrm{effi}}^{\beta}=\varphi_{\mathrm{i}} \varepsilon_{\mathrm{i}}^{\beta}+\varphi_{\mathrm{phi}} \varepsilon_{\mathrm{phi}}^{\beta}+\varphi_{\mathrm{m}} \varepsilon_{\mathrm{m}}^{\beta}$

Where $\varphi_{\mathrm{i}}$ is the volume fraction of first filler component of the composite system, $\varphi_{\mathrm{phi}}$ is the volume fraction of the interphase region component of the composite system, $\varphi_{\mathrm{m}}$ is the volume fraction of the matrix component of the composite, $\varepsilon_{\text {effi }}$ is the dielectric permittivity of the composite system, $\varepsilon_{i}$ is the filler permittivity of the composite system, $\varepsilon_{\text {phi }}$ is the interphase permittivity of the composite system, $\varepsilon_{\mathrm{m}}$ is the the matrix permittivity of the composite system.

Whatever, the effective dielectric constant of the inclusion and interphase could be expressed for multiple Nanocomposite model that contains an interphase region according to [13], [18] as

$\varepsilon_{\mathrm{effj}}^{\beta}=\varphi_{\mathrm{j}} \varepsilon_{\mathrm{j}}^{\beta}+\varphi_{\mathrm{phij}} \varepsilon_{\mathrm{phij}}^{\beta}+\varphi_{\mathrm{effi}} \varepsilon_{\mathrm{effi}}^{\beta}$

Where, $\varphi_{\mathrm{j}}$ is the volume fraction of second filler component of the composite system, $\varphi_{\mathrm{phij}}$ is the volume fraction of the interphase region component of the composite system, $\varphi_{\text {effi }}$ is the volume fraction of the matrix component of the composite, $\varepsilon_{\text {effj }}$ is the dielectric permittivity of the composite system, $\varepsilon_{\mathrm{j}}$ is the second filler permittivity of the composite system, $\varepsilon_{\text {phij }}$ is the interphase permittivity of the composite system, $\varepsilon_{\text {effi }}$ is the dielectric permittivity of the individual nanocomposites system.

\section{MODEL CONFIGURITION}

This paper investigates two models of cable configuration. The first model is single core power cable as shown in Fig 1 and the second model is three core belted power cable as shown in Fig 2. The two-model configuration setup according to standard dimensions designed by Nexans Energy Networks Company, Design 
Standards 6622 - BS 7835[22]. Table (1) shows the two models configuration of Single- and Three-Core power cables. The void diameter is considered $1 \mathrm{~mm}$ located between the conductor surface and the insulation inner surface [23]. Finite Element Methods Magnetics (FEMM) software is used for this simulation. Finite Element Method Magnetics (FEMM) software is a finite element package. This software is used for solving 2dimensional planar and axisymmetric problems in electrostatics, current flow, heat flow and low frequency magnetics [2].

Table 1 Configuration of Single- and Three-Core Cables [22]- [24]

\begin{tabular}{|c|c|c|c|}
\hline \multicolumn{2}{|l|}{ Single-Core Power Cables } & \multicolumn{2}{|l|}{ Three-Core Power Cables } \\
\hline Specification & Rating & Specification & Rating \\
\hline Rated voltage $(\mathrm{kV})$ & 11 & Rated voltage $(\mathrm{kV})$ & 33 \\
\hline Number core & 1 & Number core & 3 \\
\hline Nominal cross-sectional area (mm) & 150 & Nominal cross-sectional area (mm) & 150 \\
\hline Diameter over conductor (mm) & 14.3 & Diameter over conductor (mm) & 14.3 \\
\hline Approximate diameter over insulation (mm) & 22.2 & Approximate diameter over insulation (mm) & 26.5 \\
\hline Water permittivity & 81 & Water permittivity & 81 \\
\hline Air permittivity & 1 & Air permittivity & 1 \\
\hline Cupper impurity permittivity & 5.6 & Cupper impurity permittivity & 5.6 \\
\hline Radius of bubble (mm) & 0.5 & Radius of bubble (mm) & 0.5 \\
\hline
\end{tabular}

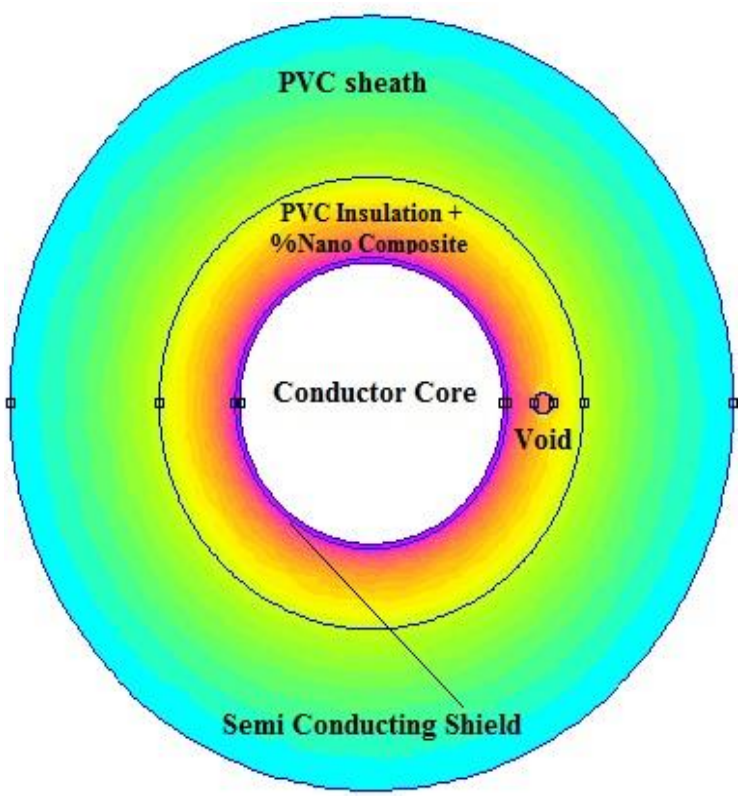

Figure 1. Cross section of single core cable with void

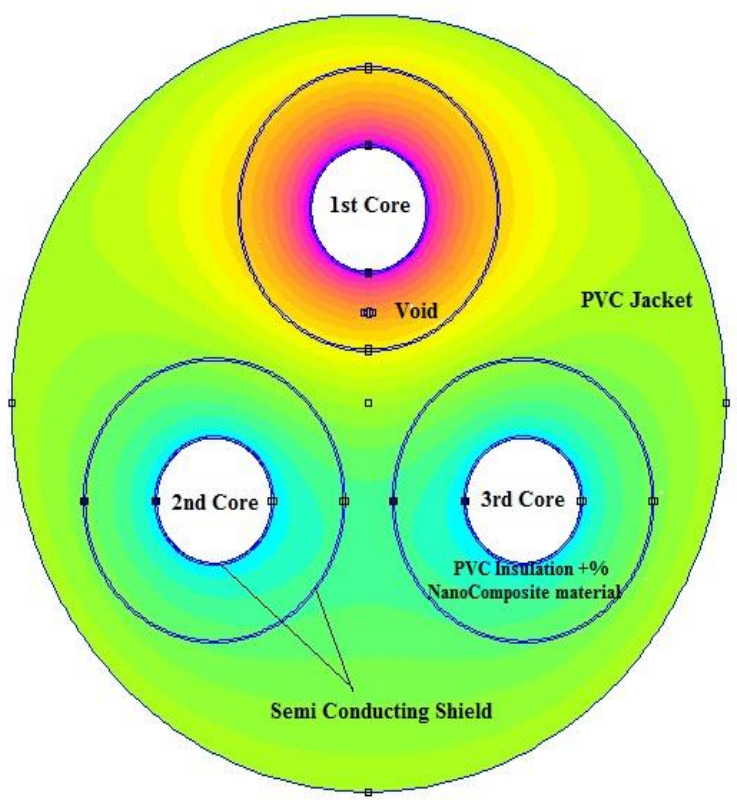

Figure 2. Cross section of Three core cable with void

\section{SELECTED MATERIALS AND PARAMETERS}

Polyvinyl Chloride (PVC) is the most widely used of any of cables, thermoplastics, polymerized vinyl chloride and is produced from ethylene and anhydrous hydrochloric acid. PVC is stronger and more rigid than other general-purpose thermoplastic materials, tough, strong, resist water, abrasion, and are excellent electrical insulators [16]. Clay nanoparticles are used to reduce the density of product [17]. Aluminum Oxide $\left(\mathrm{Al}_{2} \mathrm{O}_{3}\right)$ is strong high heat-resistance, very stable, high hardness, high mechanical strength, and electrical insulator. Magnesium Oxide $(\mathrm{MgO})$ has high thermal conductivity and low electrical conductivity, whatever, Barium titanite $\left(\mathrm{BaTiO}_{3}\right)$ is a dielectric ceramic used for capacitors. Ferric oxide $\left(\mathrm{Fe}_{2} \mathrm{O}_{3}\right)$ is used in Pigment, Polishing, Photocatalysis. Titanium dioxide $\left(\mathrm{TiO}_{2}\right)$ is used in electrical ceramics, metal patinas, catalysts, electric conductors and chemical intermediates. Table 2 depicts the details of numerical dielectric constant values of selected nanocomposite and multi-nanocomposite is computed by MATLAB Program depended on modified power law model equations for enhancing the performance of Polyvinyl Chloride insulators [7]. Also, electric conductivity of selected nanocomposite and multi-nanocomposite is computed by electrical conductivity equation [21]. 
Table 2. Dielectric Constant of Polyvinyl Chloride Nanocomposites and Multi-Nanocomposites Materials

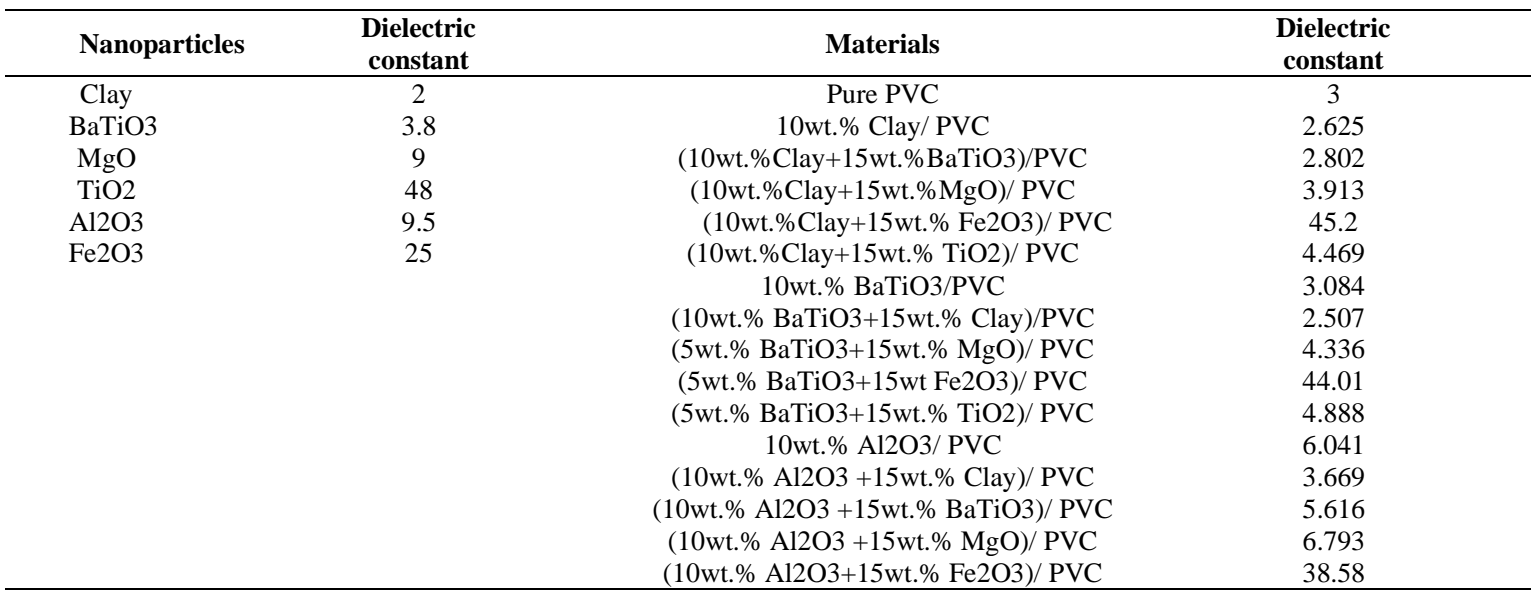

\section{RESULTS AND ANALYSIS}

The electric field stress can be controlled by changing relative permittivity of insulator material by adding individual nanocomposite or multi-nanocomposite materials to insulator material. Also getting new dielectric materials due to our needs for enhancing electric applications. The following results illustrate the behavior of electric field stress inside nanocomposites and multi nanocomposites insulation materials of power cables which having (air - impurity - water) voids.

\subsection{Electric Stress in Single-Core Cables}

Figures 3-5 illustrate the behavior of electric stress within variant polyvinyl chloride insulation materials pure and nanocomposites in case of presence air void. It has been observed that adding concentration of (10wt. $\% \mathrm{Al}_{2} \mathrm{O}_{3}+15 \mathrm{wt} . \% \mathrm{Fe}_{2} \mathrm{O}_{3}$ ) nanoparticles to polyvinyl chloride decreases the electric field distribution about $82.9 \%$ inside air void and decreases the electric field distribution inside power cable insulation about $86.8 \%$ due to the effect of high dielectric constant of $\mathrm{Al}_{2} \mathrm{O}_{3}$ and $\mathrm{Fe}_{2} \mathrm{O}_{3}$ nanoparticles. On the other side it has been observed that adding concentration of $\left(10 \mathrm{wt} . \% \mathrm{Al}_{2} \mathrm{O}_{3}+15 \mathrm{wt}\right.$. \% Clay) nanoparticles to polyvinyl chloride decreases the electric field distribution about $6.95 \%$ inside air void and decreases the electric field distribution inside power cable insulation about $11.4 \%$ due to the effect of low dielectric constant of Clay nanoparticle. And other composite electric distribution graded between them as shown in Fig. 3. Moreover, it has been observed that adding concentration of $\left(10 \mathrm{wt} . \% \mathrm{BaTiO}_{3}+15 \mathrm{wt} . \% \mathrm{Fe}_{2} \mathrm{O}_{3}\right)$ nanoparticles to polyvinyl chloride decreases the electric field distribution about $84.8 \%$ inside air void and decreases the electric field distribution inside power cable insulation about $88.4 \%$ due to the effect of high dielectric constant of $\mathrm{Fe}_{2} \mathrm{O}_{3}$ nanoparticles. On the other side, it has been observed that adding concentration of $\left(10 \mathrm{wt} \% \mathrm{BaTiO}_{3}+15 \mathrm{wt} . \% \mathrm{Clay}\right)$ nanoparticles to polyvinyl chloride increases the electric field distribution about $5.34 \%$ inside air void and increases the electric field distribution inside power cable insulation about $10.6 \%$ due to the effect of low dielectric constant of $\mathrm{BaTiO}_{3}$ and Clay nanoparticles. And other composite electric distribution graded between them as shown in Fig. 4. Finally, it has been observed that adding concentration of (10wt.\%Clay+15wt.\% $\mathrm{Fe}_{2} \mathrm{O}_{3}$ ) nanoparticles to polyvinyl chloride decreases the electric field distribution about $85.1 \%$ inside air void and decreases the electric field distribution inside power cable insulation about $88.7 \%$ due to the effect of high dielectric constant of $\mathrm{Fe}_{2} \mathrm{O}_{3}$ nanoparticles. On the other side, it has been observed that adding concentration of $\left(10 \mathrm{wt} . \% \mathrm{Clay}+15 \mathrm{wt} . \% \mathrm{BaTiO}_{3}\right)$ nanoparticles to polyvinyl chloride increases the electric field distribution about $2.13 \%$ inside air void and increases the electric field distribution inside power cable insulation about $4.25 \%$ due to the effect of low dielectric constant of $\mathrm{BaTiO}_{3}$ and Clay nanoparticles. And other composite electric distribution graded between them as shown in Fig. 5. And so, increasing the concentration of $\mathrm{Fe}_{2} \mathrm{O}_{3}$ nanoparticle causes more effect for decreasing electric field distribution inside air void. And so, it has observed different behavior to electric stress performance in case of adding multiple nanoparticles inside polyvinyl chloride. 


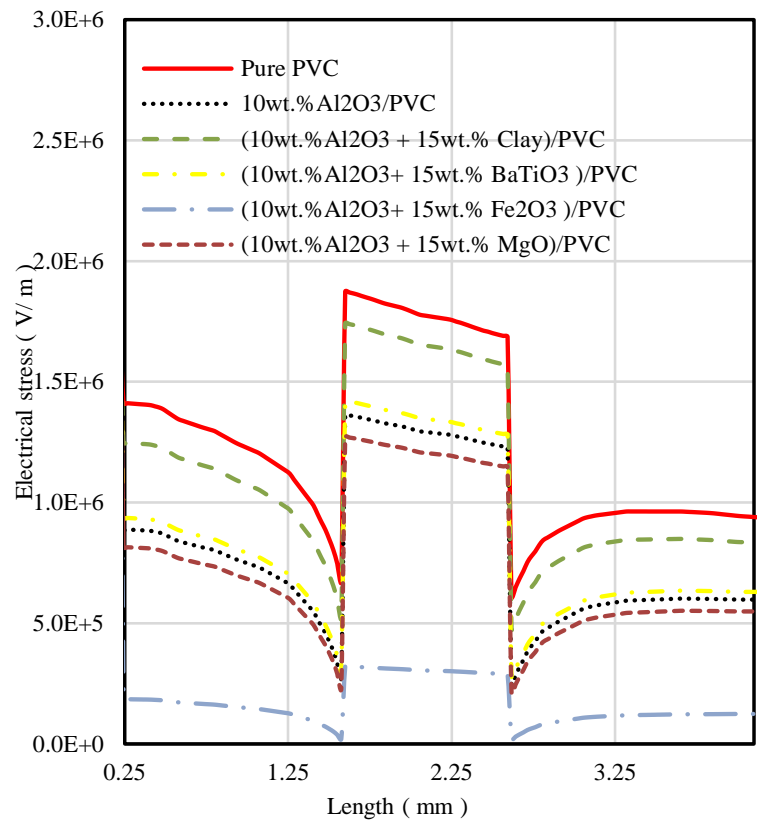

Figure 3. Electric field distribution in cable insulation with air void

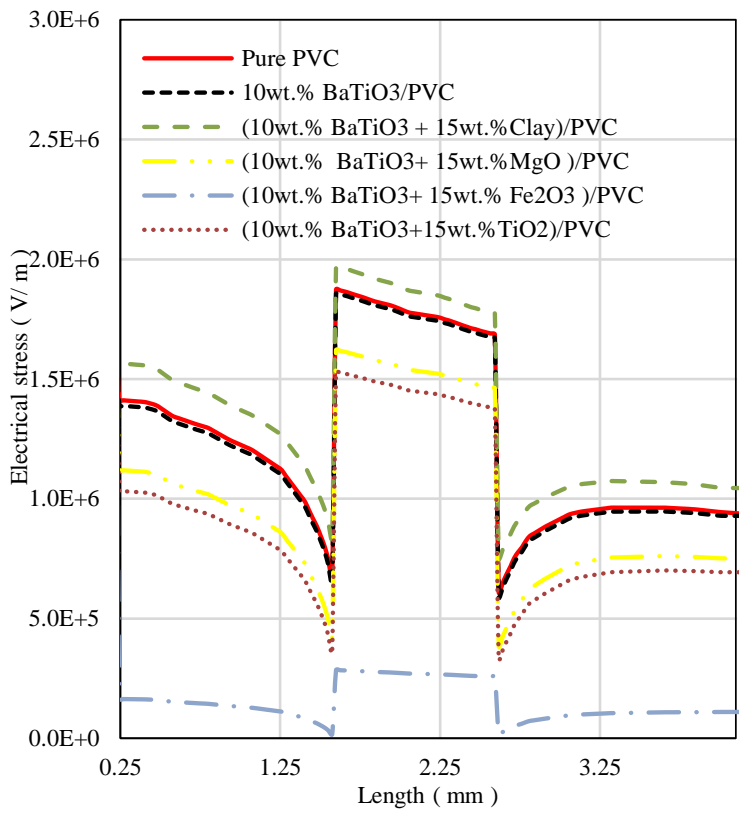

Figure 4. Electric field distribution in cable insulation with air void

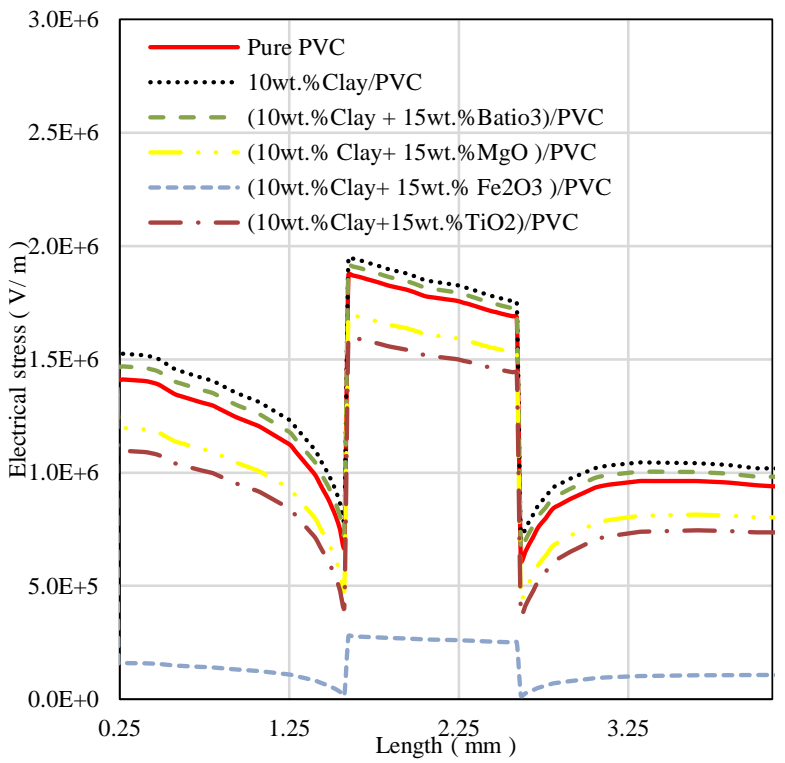

Figure 5. Electric field distribution in cable insulation with air void

Figures 6-8 illustrate the behaviour of electric stress within variant polyvinyl chloride insulation materials pure and nanocomposites in case of presence water void. It has been observed that adding concentration of ( $10 \mathrm{wt} . \% \mathrm{Al}_{2} \mathrm{O}_{3}+15 \mathrm{wt} . \% \mathrm{Fe}_{2} \mathrm{O}_{3}$ ) nanoparticle to polyvinyl chloride decreases the electric field distribution about $13.02 \%$ inside water void and decreases the electric field distribution inside power cable insulation about $88 \%$ due to the effect of high dielectric constant of $\mathrm{Al}_{2} \mathrm{O}_{3}$ and $\mathrm{Fe}_{2} \mathrm{O}_{3}$ nanoparticles. On the other side it has been observed that adding concentration of $\left(10 \mathrm{wt} . \% \mathrm{Al}_{2} \mathrm{O}_{3}+15 \mathrm{wt} . \%\right.$ Clay) nanoparticles to polyvinyl chloride decreases the electric field distribution about $7.21 \%$ inside water void and decreases the electric field distribution inside power cable insulation about $12.2 \%$ due to the effect of low dielectric constant of Clay nanoparticle. And other composite electric distribution graded between them as shown in Fig. 6. (a). Electric stress distribution inside water void shown in Fig. 6. (b), it has been observed that adding concentration of $\left(10 \mathrm{wt} . \% \mathrm{BaTiO}_{3}+15 \mathrm{wt} . \% \mathrm{Fe}_{2} \mathrm{O}_{3}\right)$ nanoparticles to polyvinyl chloride decreases the electric field distribution about $8.71 \%$ inside water void and decreases the electric field distribution inside power cable insulation about 89.5\% due to the effect of high dielectric constant of $\mathrm{Fe}_{2} \mathrm{O}_{3}$ nanoparticle. On the other side, it has been observed 
that adding concentration of ( $10 \mathrm{wt} . \% \mathrm{BaTiO}_{3}+15 \mathrm{wt} . \%$ Clay) nanoparticles to polyvinyl chloride increases the electric field distribution about $7.31 \%$ inside water void and increases the electric field distribution inside power cable insulation about $10.4 \%$ due to the effect of low dielectric constant of $\mathrm{BaTiO}_{3}$ and Clay nanoparticles. And other composite electric distribution graded between them as shown in Fig.7. (a). Electric stress distribution inside water void shown in Fig.7(b).
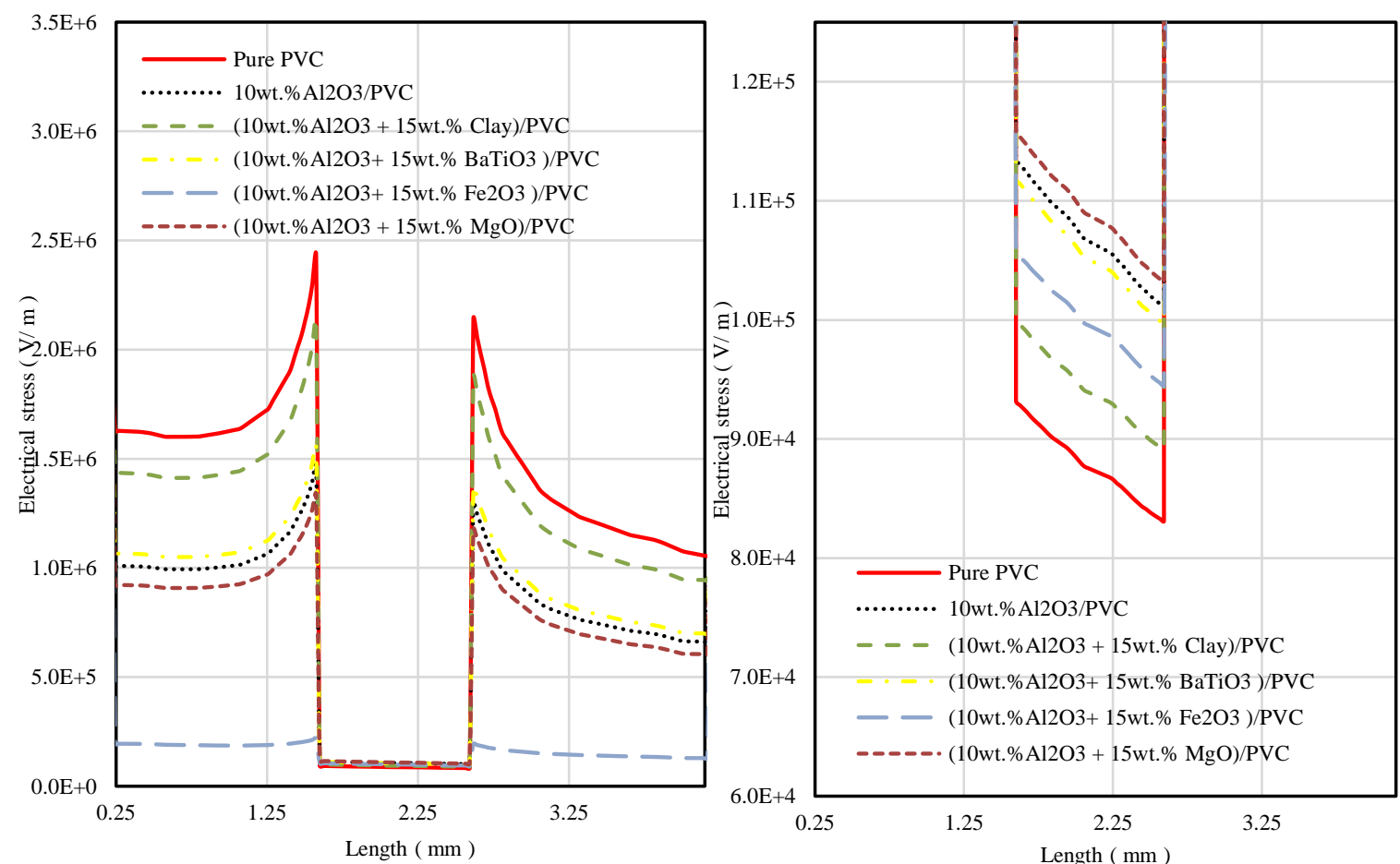

Figure 6. (a) Electric field distribution in cable insulation Figure 6. (b) Stress distribution inside water void
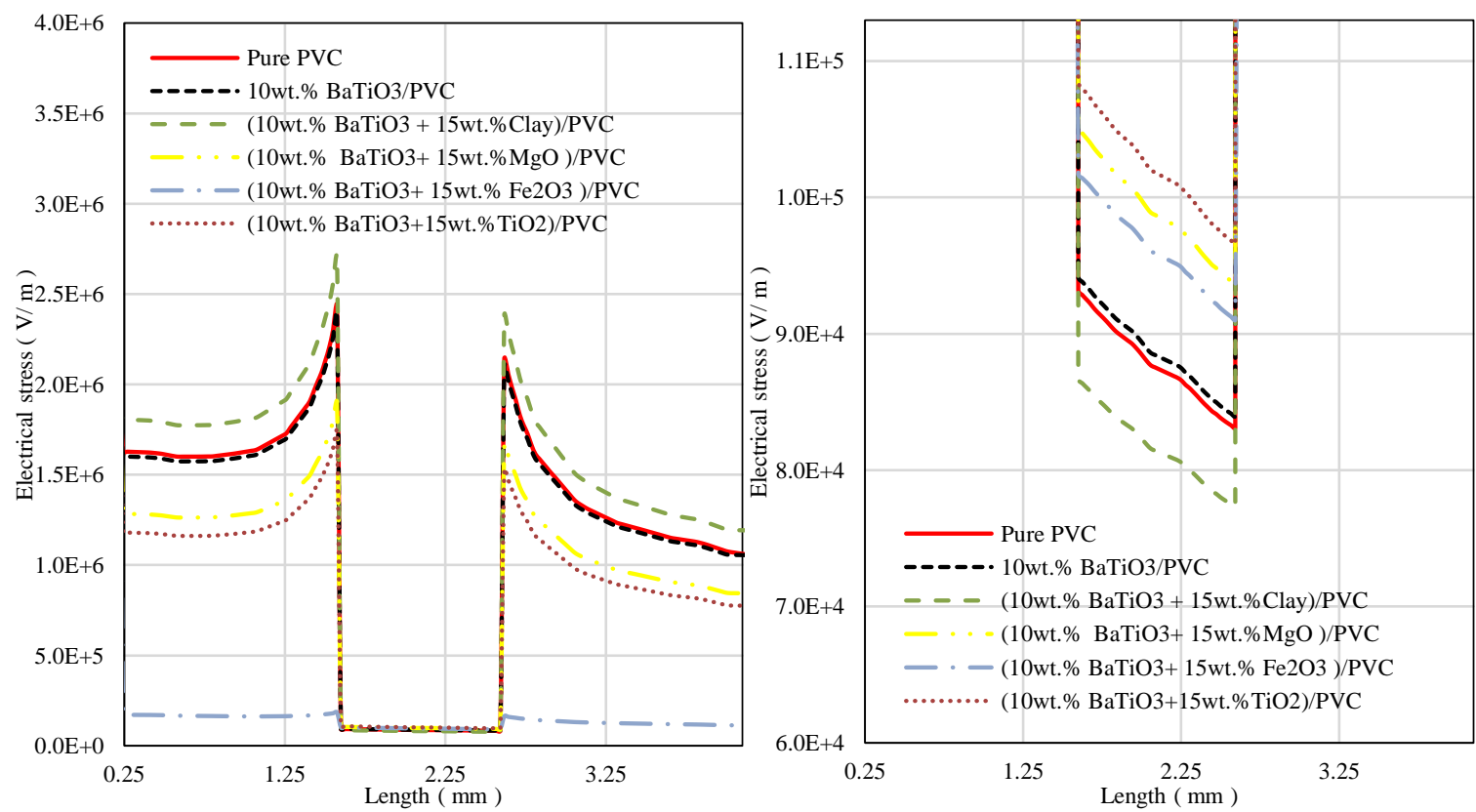

Figure 7. (a) Electric field distribution in cable insulation Figure 7. (b) Stress distribution inside water void 

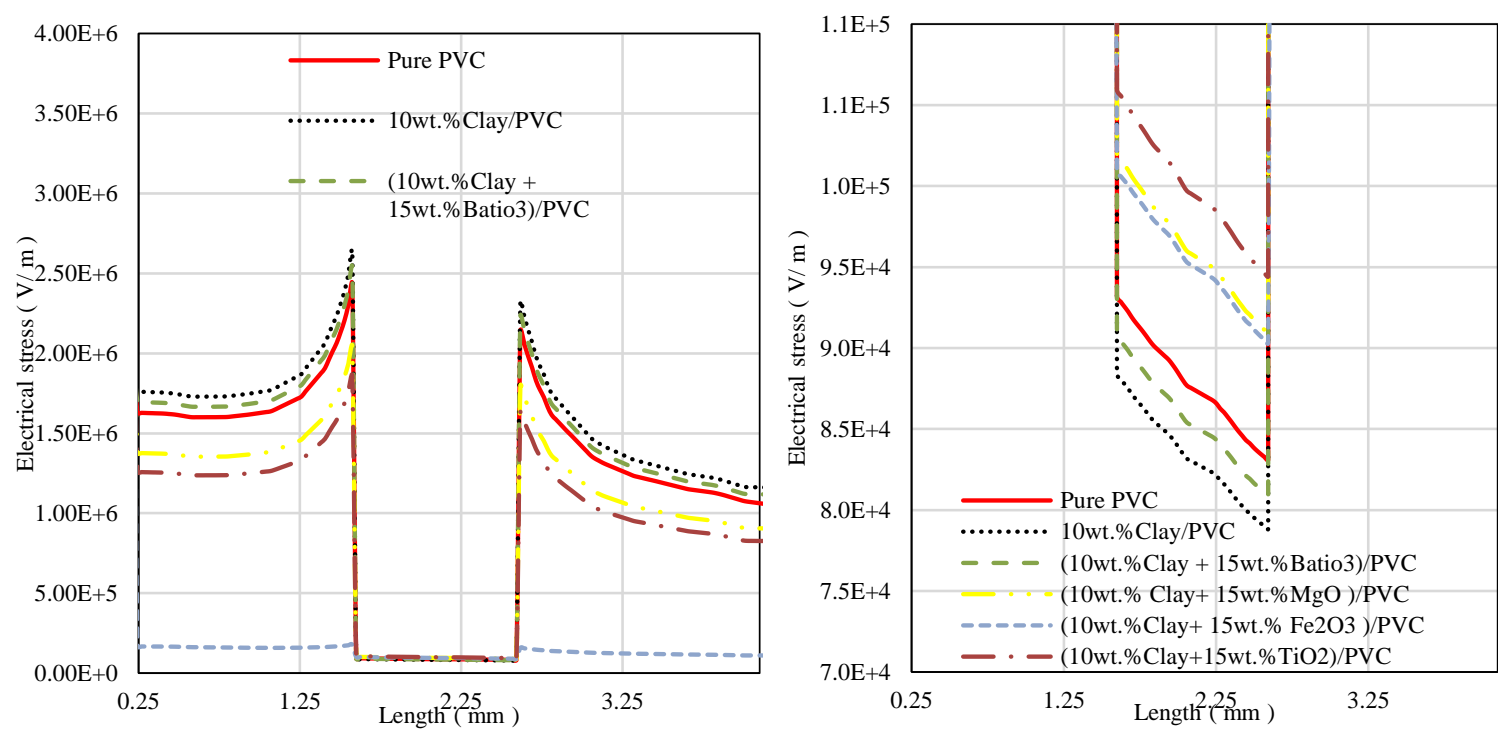

Figure 8. (a) Electric field distribution in cable insulation Figure 8. (b) Stress distribution within water void

Finally, it has been observed that adding concentration of (10wt.\%Clay+15wt. $\left.\% \mathrm{Fe}_{2} \mathrm{O}_{3}\right)$ nanoparticles to polyvinyl chloride decreases the electric field distribution about $7.64 \%$ inside water void and decreases the electric field distribution inside power cable insulation about $89.7 \%$ due to the effect of high dielectric constant of $\mathrm{Fe}_{2} \mathrm{O}_{3}$ nanoparticle. From the other side it has been observed that adding concentration of (10wt.\%Clay +15 wt. $\% \mathrm{BaTiO}_{3}$ ) nanoparticles to polyvinyl chloride increases the electric field distribution about $2.69 \%$ inside water void and increases the electric field distribution inside power cable insulation about $3.68 \%$ due to the effect of low dielectric constant of $\mathrm{BaTiO}_{3}$ and Clay nanoparticles. Also, when adding concentration of (10wt.\% Clay) nanoparticles to polyvinyl chloride electric stress inside cable insulator be in higher value than adding concentration of (10wt. $\%$ Clay $\left.+15 \mathrm{wt} . \% \mathrm{BaTiO}_{3}\right)$ nanoparticles to polyvinyl chloride and other composite electric distribution graded between them as shown in Fig.8. (a). Electric stress distribution inside water void shown in Fig.8. (b), it is obvious that increasing the concentration of $\mathrm{Fe}_{2} \mathrm{O}_{3}$ nanoparticles causes more effect for decreasing electric field distribution inside water void. And it has observed different behaviour to electric stress performance in case of adding multiple nanoparticles inside polyvinyl chloride.

Figures 9-11 illustrate the behaviour of electric stress within variant polyvinyl chloride insulation materials pure and nanocomposites in case of presence cupper impurity void. It has been observed that adding concentration of $\left(10 \mathrm{wt} . \% \mathrm{Al}_{2} \mathrm{O}_{3}+15 \mathrm{wt} . \% \mathrm{Fe}_{2} \mathrm{O}_{3}\right)$ nanoparticles to polyvinyl chloride decreases the electric field distribution about $67.7 \%$ inside impurity void and decreases the electric field distribution inside power cable insulation about $87.8 \%$ due to the effect of high dielectric constant of $\mathrm{Al}_{2} \mathrm{O}_{3}$ and $\mathrm{Fe}_{2} \mathrm{O}_{3}$ nanoparticles. On the other side, it has been observed that adding concentration of $\left(10 \mathrm{wt} . \% \mathrm{Al}_{2} \mathrm{O}_{3}+15 \mathrm{wt}\right.$. \% Clay) nanoparticles to polyvinyl chloride decreases the electric field distribution about $0 \%$ inside impurity void and decreases the electric field distribution inside power cable insulation about $12.4 \%$ due to the effect of low dielectric constant of Clay nanoparticle. And other composite electric distribution graded between them as shown in Fig. 9. Moreover, it has been observed that adding concentration of $\left(10 \mathrm{wt} . \% \mathrm{BaTiO}_{3}+15 \mathrm{wt} . \% \mathrm{Fe}_{2} \mathrm{O}_{3}\right)$ nanoparticles to polyvinyl chloride decreases the electric field distribution about $71.1 \%$ inside impurity void and decreases the electric field distribution inside power cable insulation about $89.2 \%$ due to the effect of high dielectric constant of $\mathrm{Fe}_{2} \mathrm{O}_{3}$ nanoparticle. On the other side it has been observed that adding concentration of (10wt.\% $\mathrm{BaTiO}_{3}+15 \mathrm{wt}$.\%Clay) nanoparticles to polyvinyl chloride increases the electric field distribution about $2.13 \%$ inside impurity void and increases the electric field distribution inside power cable insulation about $11.1 \%$ due to the effect of low dielectric constant of $\mathrm{BaTiO}_{3}$ and Clay nanoparticles. And other composite electric distribution graded between them as shown in Fig.10(a). Electric stress distribution inside cupper impurity void shown in Fig.10(b).

IJEEI, Vol. 9, No. 1, March 2021: 8-21 


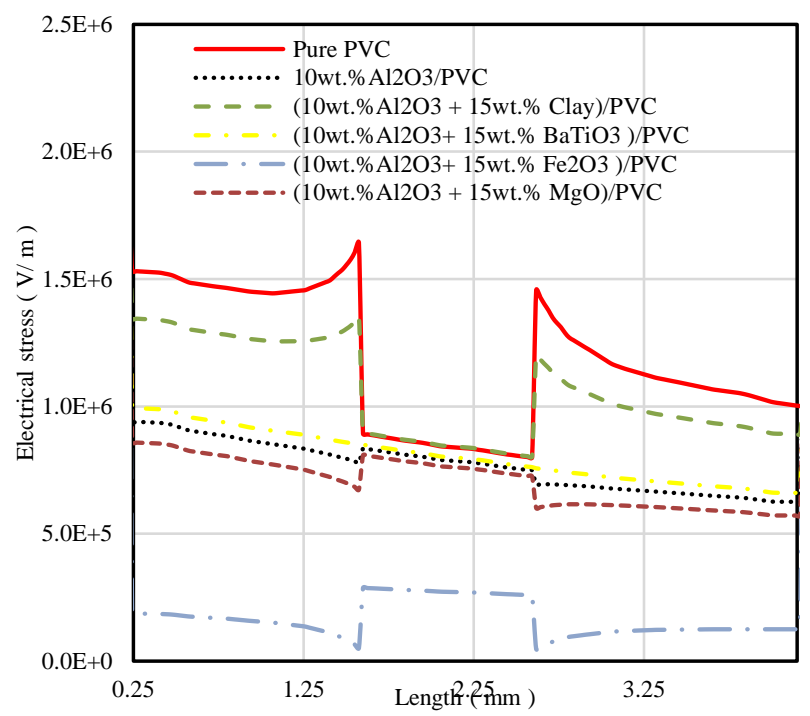

Figure 9. Electric field distribution in cable insulation with copper impurity void

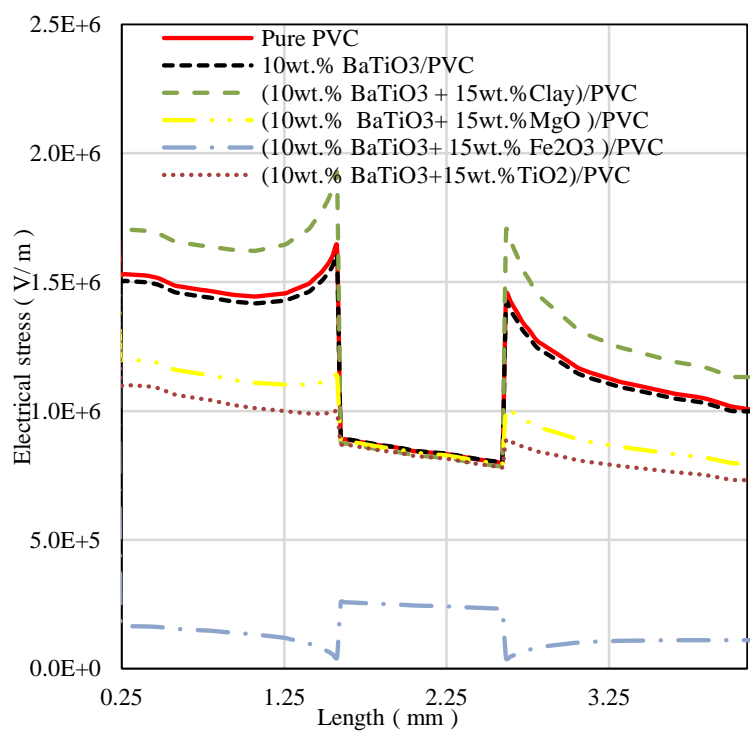

Figure 10. (a) Electric field distribution in cable insulation

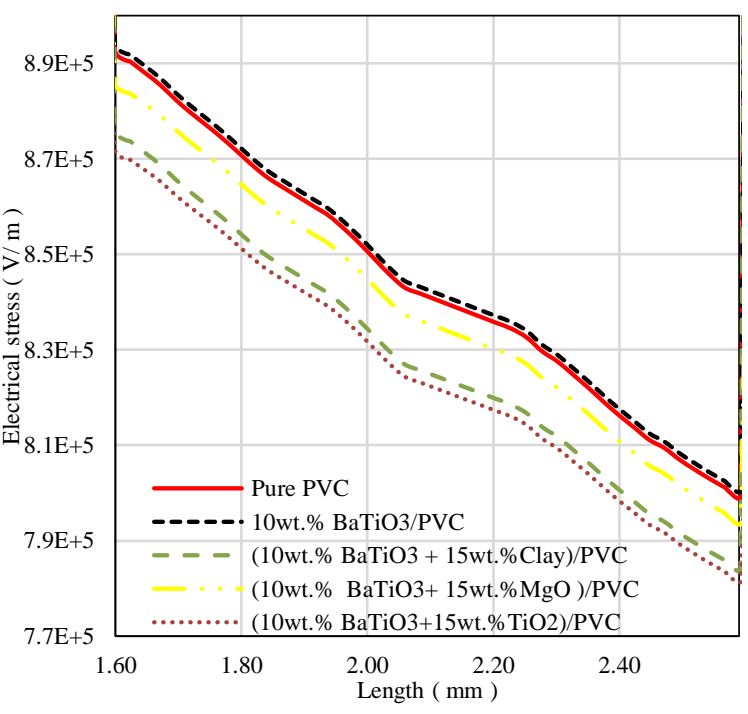

Figure 10. (b) Stress distribution inside

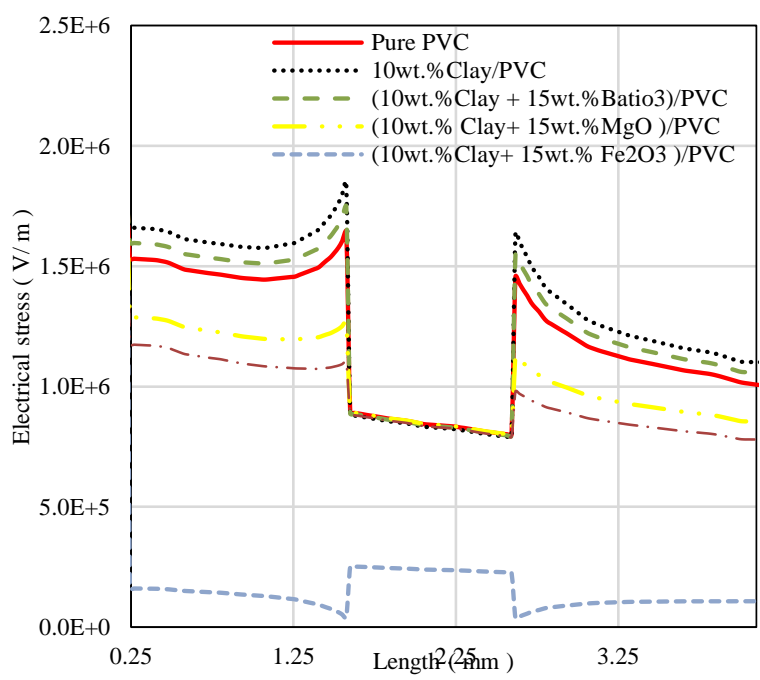

Figure 11. (a) Electric field distribution in cable insulation

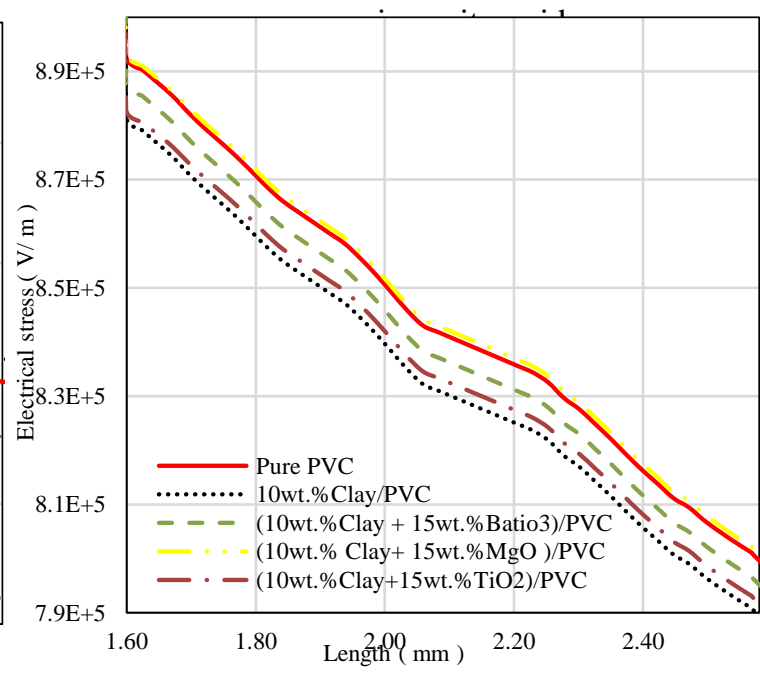

Figure 11. (b) Stress distribution inside impurity void 
Finally, it has been observed that adding concentration of (10wt. $\%$ Clay+15wt. $\left.\% \mathrm{Fe}_{2} \mathrm{O}_{3}\right)$ nanoparticles to polyvinyl chloride decreases the electric field distribution about $71.7 \%$ inside cupper impurity void and decreases the electric field distribution inside power cable insulation about $89.5 \%$ due to the effect of high dielectric constant of $\mathrm{Fe}_{2} \mathrm{O}_{3}$ nanoparticle. From the other side it has been observed that adding concentration of (10wt.\% Clay $\left.+15 \mathrm{wt} . \% \mathrm{BaTiO}_{3}\right)$ nanoparticles to polyvinyl chloride increases the electric field distribution about $0.56 \%$ inside impurity void and increases the electric field distribution inside power cable insulation about $4.57 \%$ due to the effect of low dielectric constant of $\mathrm{BaTiO}_{3}$ and Clay nanoparticles. In case of adding concentration of (10wt.\% Clay) nanoparticles to polyvinyl chloride, the electric stress inside cable insulator be in higher value than adding concentration of $\left(10 \mathrm{wt} . \%\right.$ Clay $\left.+15 \mathrm{wt} . \% \mathrm{BaTiO}_{3}\right)$ nanoparticles to polyvinyl chloride and other composite electric distribution graded between them as shown in Fig.11. (a). Electric stress distribution inside impurity void shown in Fig.11. (b). it is obvious that increasing the concentration of $\mathrm{Fe}_{2} \mathrm{O}_{3}$ nanoparticle causes more effect for decreasing electric field distribution inside cupper impurity void. And so, it has observed different behavior to electric stress performance in case of adding multiple nanoparticles inside polyvinyl chloride.

\subsection{Electric Stress in Three-Core Power Cable}

Figures (12-14) illustrate the behaviour of electric stress within variant polyvinyl chloride insulation materials pure and nanocomposites in case of presence air void in three core belted power cable. Electric stress distribution is drawn around first core axis passes through air void. It has been observed that adding concentration of $\left(10 \mathrm{wt} . \% \mathrm{Al}_{2} \mathrm{O}_{3}+15 \mathrm{wt} . \% \mathrm{Fe}_{2} \mathrm{O}_{3}\right.$ ) nanoparticles to polyvinyl chloride decreases the electric field distribution about $82.4 \%$ inside air void and decreases the electric field distribution inside power cable insulation about $82.1 \%$ due to the effect of high dielectric constant of $\mathrm{Al}_{2} \mathrm{O}_{3}$ and $\mathrm{Fe}_{2} \mathrm{O}_{3}$ nanoparticles. On the other side, it has been observed that adding concentration of $\left(10 \mathrm{wt} . \% \mathrm{Al}_{2} \mathrm{O}_{3}+15 \mathrm{wt}\right.$. \% Clay) nanoparticles to polyvinyl chloride decreases the electric field distribution about $6.38 \%$ inside air void and decreases the electric field distribution inside power cable insulation about $7.69 \%$ due to the effect of low dielectric constant of Clay nanoparticle. And other composite electric distribution graded between them as shown in Fig.12. (a). Electric stress distribution inside air void shown in Fig.12. (b). it has been observed that adding concentration of $\left(10 \mathrm{wt} . \% \mathrm{BaTiO}_{3}+15 \mathrm{wt} . \% \mathrm{Fe}_{2} \mathrm{O}_{3}\right)$ nanoparticles to polyvinyl chloride decreases the electric field distribution about $84.3 \%$ within air void and decreases the electric field distribution inside power cable insulation about $84.1 \%$ due to the effect of high dielectric constant of $\mathrm{Fe}_{2} \mathrm{O}_{3}$ nanoparticle. On the other side it has been observed that adding concentration of ( $\left.10 \mathrm{wt} . \% \mathrm{BaTiO}_{3}+15 \mathrm{wt} . \% \mathrm{Clay}\right)$ nanoparticles to polyvinyl chloride increases the electric field distribution about $4.72 \%$ within air void and increases the electric field distribution inside power cable insulation about $6.83 \%$ due to the effect of low dielectric constant of $\mathrm{BaTiO}_{3}$ and $\mathrm{Clay}$ nanoparticles. And other composite electric distribution graded between them as shown in Fig.13. (a). Electric stress distribution inside air void shown in Fig.13. (b).

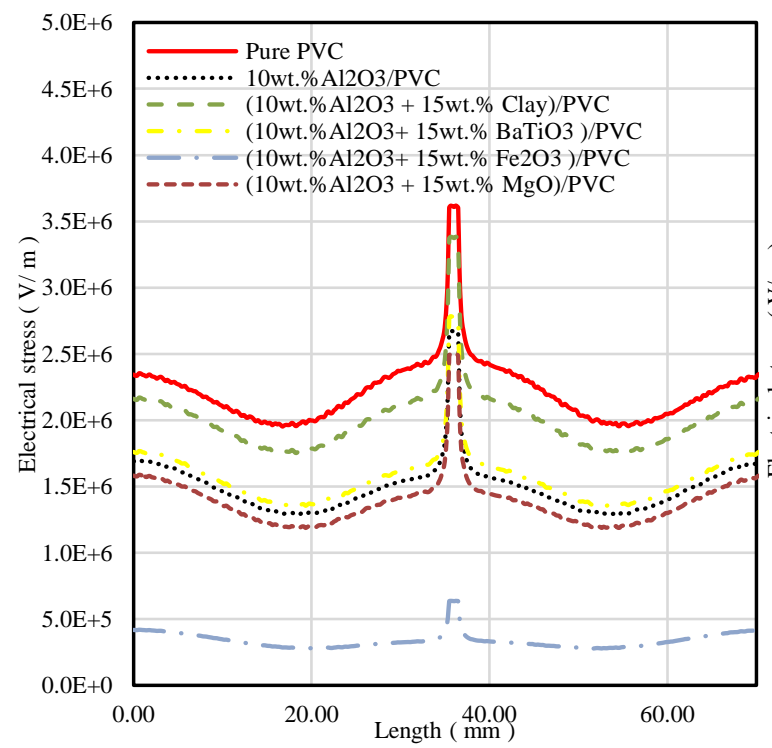

Figure 12. (a) Electric field distribution in cable insulation

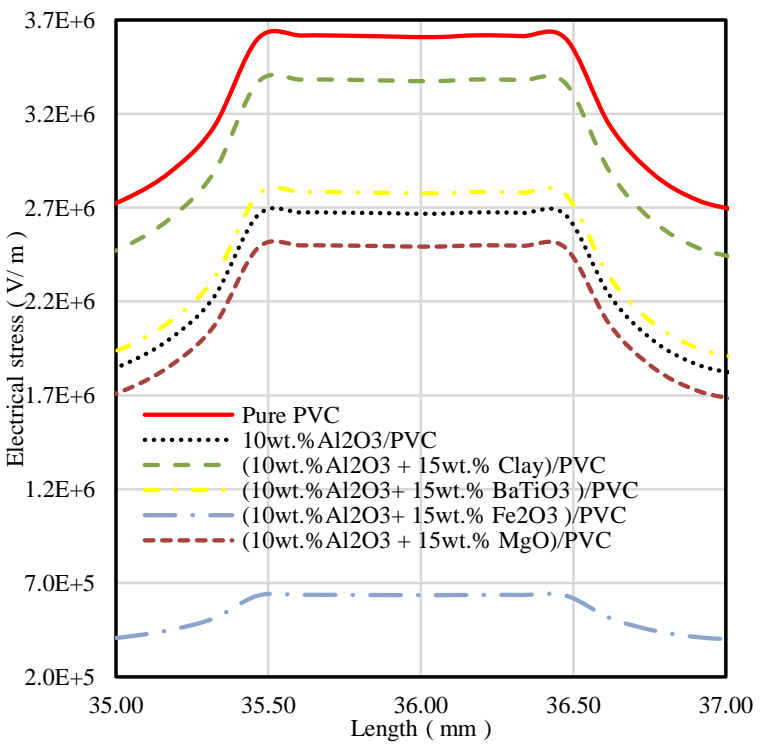

Figure 12. (b) Stress distribution inside air void 


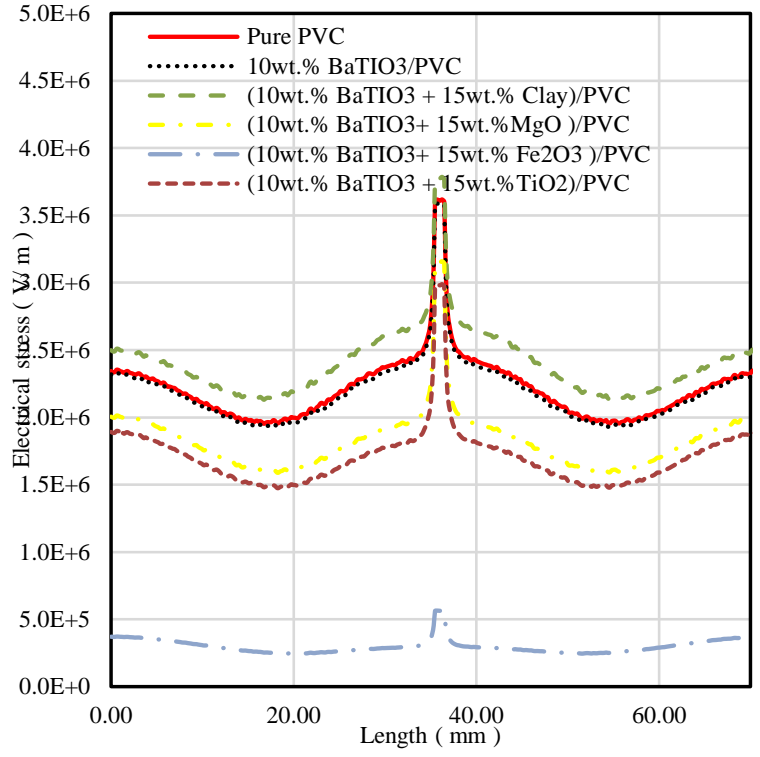

Figure 13. (a) Electric field distribution in cable insulation

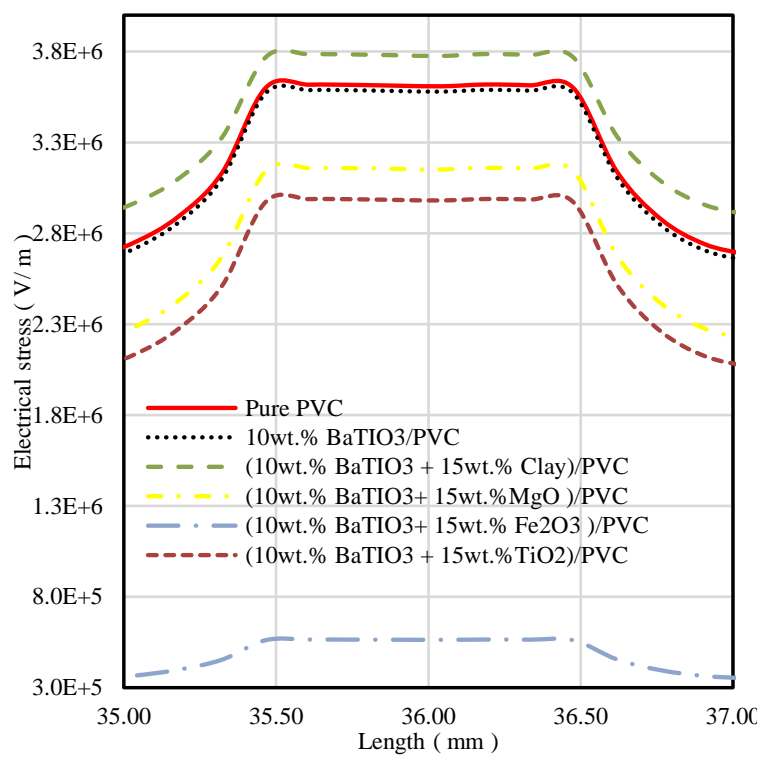

Figure 13. (b) Stress distribution inside air void

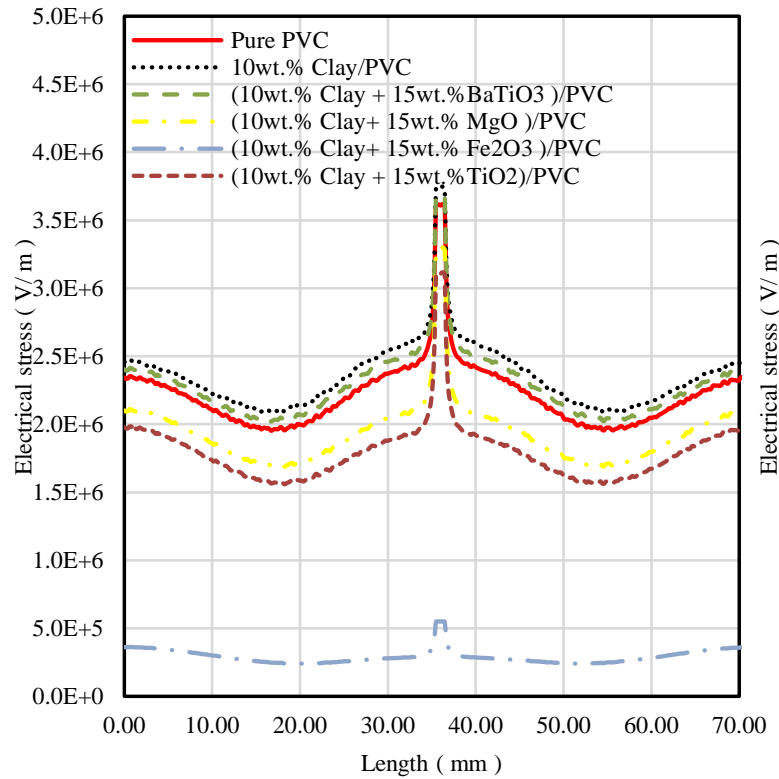

Figure 14. (a) Electric field distribution in cable insulation

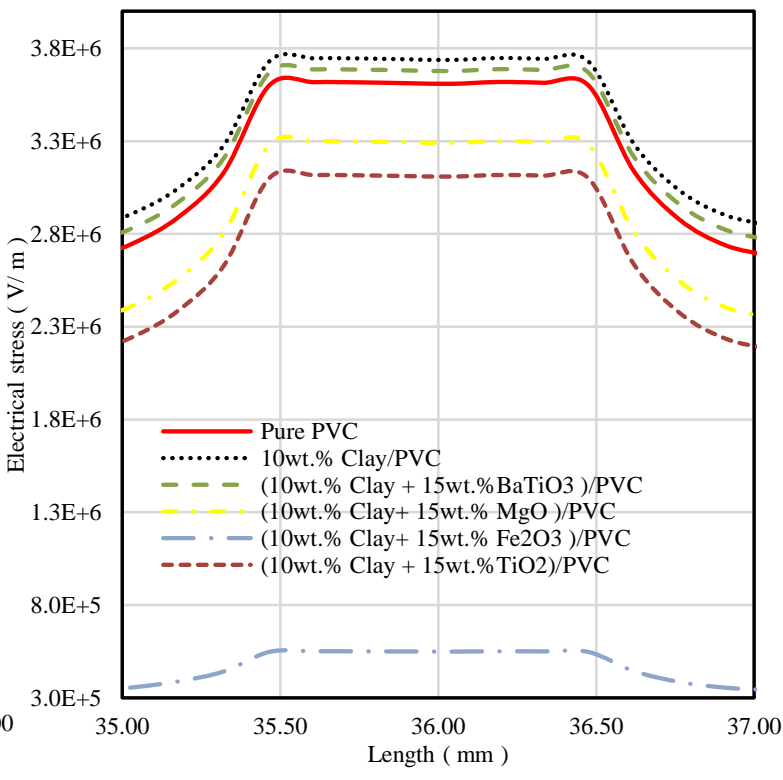

Figure 14. (b) Stress distribution inside air void

Finally, it has been observed that adding concentration of $\left(10 \mathrm{wt} . \% \mathrm{Clay}+15 \mathrm{wt} . \% \mathrm{Fe}_{2} \mathrm{O}_{3}\right)$ nanoparticles to polyvinyl chloride decreases the electric field distribution about $84.7 \%$ inside air void and decreases the electric field distribution inside power cable insulation about $84.5 \%$ due to the effect of high dielectric constant of $\mathrm{Fe}_{2} \mathrm{O}_{3}$ nanoparticle. On the other side, it has been observed that adding concentration of (10wt.\%Clay +15wt. $\% \mathrm{BaTiO}_{3}$ ) nanoparticles to polyvinyl chloride increases the electric field distribution about $1.94 \%$ inside air void and increases the electric field distribution inside power cable insulation about $2.56 \%$ due to the effect of low dielectric constant of $\mathrm{BaTiO}_{3}$ and Clay nanoparticles. Also, when adding concentration of (10wt.\% Clay) nanoparticles to polyvinyl chloride, electric stress inside cable insulator be in higher value than adding concentration of $\left(10 \mathrm{wt} . \%\right.$ Clay $+15 \mathrm{wt}$ \% $\left.\mathrm{BaTiO}_{3}\right)$ nanoparticles to polyvinyl chloride and other composite electric distribution graded between them as shown in Fig.14. (a). Electric stress distribution inside air void shown in Fig.14. (b). it noticed that increasing the concentration of $\mathrm{Fe}_{2} \mathrm{O}_{3}$ nanoparticle causes more effect for decreasing electric field distribution inside air void. It has observed different behavior to electric stress performance in case of adding multiple nanoparticles inside polyvinyl chloride. 


\section{TRENDS OF USING MODERN NANOCOMPOSITES INSULATION}

For the manufacturing of power cables, insulating fillers such as layered silicates, montmorillonite clays, $\mathrm{Al}_{2} \mathrm{O}_{3}, \mathrm{TiO}_{2}$ and $\mathrm{SiO}_{2}$ are used in the case of conducting fillers, graphite platelets and carbon nanotubes are among the most commonly used congeners. Such conducting fillers can enhance the mechanical properties of nanocomposites and electrical conductivity. With respect to insulating fillers, layered silicates or clays are in the range of a few $\mathrm{nm}$ in thickness and in the range of $100 \mathrm{~nm}$ in the other two dimensions, while the sizes of nanoparticles such as $\mathrm{SiO}_{2}, \mathrm{TiO}_{2}$ and $\mathrm{Al}_{2} \mathrm{O}_{3}$ are in the range of 30-40 nm [26-28].

In our research, Table 3 shows a comparison results between the electric stress inside variant nanocomposites insulation, and across air voids, water voids and copper impurities respectively for single-core power cable.

Table 3. Electric Stress inside Single-Core Cable Insulation Having Variant Voids

\begin{tabular}{|c|c|c|}
\hline \multirow{2}{*}{ Modern Nanocomposites Insulation Material } & \multicolumn{2}{|c|}{ Electric Stress in Single Core Cable $(\mathrm{kV} / \mathrm{m})$} \\
\hline & Air Void & Inside Insulation \\
\hline PURE PVC & $1.87 \mathrm{E}+3$ & $1.41 \mathrm{E}+3$ \\
\hline (10wt. $\% \mathrm{BaTiO}_{3}+15$ wt. $\left.\% \mathrm{Fe}_{2} \mathrm{O}_{3}\right) / \mathrm{PVC}$ & $2.84 \mathrm{E}+2$ & $1.64 \mathrm{E}+2$ \\
\hline$\left(10\right.$ wt. $\% \mathrm{BaTiO}_{3}+15$ wt. $\%$ Clay $) /$ PVC & $1.97 \mathrm{E}+3$ & $1.57 \mathrm{E}+3$ \\
\hline$\left(10\right.$ wt. $\%$ Clay+15wt. $\left.\% \mathrm{Fe}_{2} \mathrm{O}_{3}\right) / \mathrm{PVC}$ & $2.77 \mathrm{E}+2$ & $1.60 \mathrm{E}+2$ \\
\hline$\left(10\right.$ wt. $\%$ Clay +15 wt. $\left.\% \mathrm{BaTiO}_{3}\right) / \mathrm{PVC}$ & $1.91 \mathrm{E}+3$ & $1.47 \mathrm{E}+3$ \\
\hline \multirow{2}{*}{ Modern Nanocomposites Insulation Material } & \multicolumn{2}{|c|}{ Electric Stress in Single Core Cable $(\mathrm{kV} / \mathrm{m})$} \\
\hline & Water Void & Inside Insulation \\
\hline PURE PVC & 93.2 & $1.63 \mathrm{E}+3$ \\
\hline (10wt. $\% \mathrm{BaTiO}_{3}+15$ wt. $\left.\% \mathrm{Fe}_{2} \mathrm{O}_{3}\right) / \mathrm{PVC}$ & 102 & $1.71 \mathrm{E}+2$ \\
\hline$\left(10 \mathrm{wt} . \% \mathrm{BaTiO}_{3}+15\right.$ wt. $\%$ Clay $) /$ PVC & 86.7 & $1.81 \mathrm{E}+3$ \\
\hline$\left(10\right.$ wt. $\%$ Clay+15wt. $\left.\% \mathrm{Fe}_{2} \mathrm{O}_{3}\right) / \mathrm{PVC}$ & 101 & $1.67 \mathrm{E}+2$ \\
\hline$\left(10\right.$ wt. $\%$ Clay +15 wt. $\left.\% \mathrm{BaTiO}_{3}\right) / \mathrm{PVC}$ & 98 & $1.70 \mathrm{E}+3$ \\
\hline \multirow{2}{*}{ Modern Nanocomposites Insulation Material } & \multicolumn{2}{|c|}{ Electric Stress in Single Core Cable $(\mathrm{kV} / \mathrm{m})$} \\
\hline & Cupper Impurity Void & Inside Insulation \\
\hline PURE PVC & $8.93 \mathrm{E}+2$ & $1.53 \mathrm{E}+3$ \\
\hline (10wt. $\% \mathrm{BaTiO}_{3}+15$ wt. $\left.\% \mathrm{Fe}_{2} \mathrm{O}_{3}\right) / \mathrm{PVC}$ & $2.58 \mathrm{E}+2$ & $1.65 \mathrm{E}+2$ \\
\hline (10wt. $\% \mathrm{BaTiO}_{3}+15$ wt. $\%$ Clay $) /$ PVC & $8.76 \mathrm{E}+2$ & $1.71 \mathrm{E}+3$ \\
\hline$\left(10\right.$ wt. $\%$ Clay +15 wt. $\left.\% \mathrm{Fe}_{2} \mathrm{O}_{3}\right) / \mathrm{PVC}$ & $2.52 \mathrm{E}+2$ & $1.61 \mathrm{E}+2$ \\
\hline$\left(10 \mathrm{wt} . \%\right.$ Clay $\left.+15 \mathrm{wt} . \% \mathrm{BaTiO}_{3}\right) / \mathrm{PVC}$ & $8.88 \mathrm{E}+2$ & $1.60 \mathrm{E}+3$ \\
\hline
\end{tabular}

On the other side, Table 4 shows a comparison results between the electric stress inside variant nanocomposites insulation across air voids, respectively for three-core power cable.

Table 4. Electric Stress inside Three-Core Cable Insulation Having Variant Voids

\begin{tabular}{|c|c|c|}
\hline \multirow{2}{*}{ Modern Nanocomposites Insulation Material } & \multicolumn{2}{|c|}{ Electric Stress in Three-Core Cable $(\mathrm{kV} / \mathrm{m})$} \\
\hline & Air Void & Inside Insulation \\
\hline PURE PVC & $3.60 \mathrm{E}+3$ & $2.34 \mathrm{E}+3$ \\
\hline$\left(10 w t . \% \mathrm{BaTiO}_{3}+15\right.$ wt. $\left.\% \mathrm{Fe}_{2} \mathrm{O}_{3}\right) / \mathrm{PVC}$ & $5.62 \mathrm{E}+2$ & $3.70 \mathrm{E}+2$ \\
\hline$\left(10\right.$ wt. $\% \mathrm{BaTiO}_{3}+15$ wt. $\%$ Clay $) /$ PVC & $3.77 \mathrm{E}+3$ & $2.49 \mathrm{E}+3$ \\
\hline$\left(10 \mathrm{wt} . \%\right.$ Clay+15wt. $\left.\% \mathrm{Fe}_{2} \mathrm{O}_{3}\right) / \mathrm{PVC}$ & $5.48 \mathrm{E}+2$ & $3.61 \mathrm{E}+2$ \\
\hline$\left(10 \mathrm{wt} . \%\right.$ Clay+15wt. $\left.\% \mathrm{BaTiO}_{3}\right) / \mathrm{PVC}$ & $3.67 \mathrm{E}+3$ & $2.40 \mathrm{E}+3$ \\
\hline \multirow{2}{*}{ Modern Nanocomposites Insulation Material } & \multicolumn{2}{|c|}{ Electric Stress in Three-Core Cable $(\mathrm{kV} / \mathrm{m})$} \\
\hline & Water Void & Inside Insulation \\
\hline PURE PVC & 86.7 & $2.36 \mathrm{E}+3$ \\
\hline$\left(10\right.$ wt. $\% \mathrm{BaTiO}_{3}+15$ wt. $\left.\% \mathrm{Fe}_{2} \mathrm{O}_{3}\right) / \mathrm{PVC}$ & 149 & $2.85 \mathrm{E}+2$ \\
\hline (10wt. $\% \mathrm{BaTiO}_{3}+15 \mathrm{wt} . \%$ Clay)/ PVC & 80.3 & $2.59 \mathrm{E}+3$ \\
\hline$\left(10 w t . \%\right.$ Clay+15wt. $\left.\% \mathrm{Fe}_{2} \mathrm{O}_{3}\right) / \mathrm{PVC}$ & 149 & $2.77 \mathrm{E}+2$ \\
\hline$\left(10 w t . \%\right.$ Clay+15wt. $\left.\% \mathrm{BaTiO}_{3}\right) / \mathrm{PVC}$ & 84.8 & $2.45 \mathrm{E}+3$ \\
\hline \multirow{2}{*}{ Modern Nanocomposites Insulation Material } & \multicolumn{2}{|c|}{ Electric Stress in Three-Core Cable $(\mathrm{kV} / \mathrm{m})$} \\
\hline & Cupper Impurity Void & Inside Insulation \\
\hline PURE PVC & $1.16 \mathrm{E}+3$ & $2.40 \mathrm{E}+3$ \\
\hline$\left(10\right.$ wt. $\% \mathrm{BaTiO}_{3}+15$ wt. $\left.\% \mathrm{Fe}_{2} \mathrm{O}_{3}\right) / \mathrm{PVC}$ & $7.99 \mathrm{E}+2$ & $2.91 \mathrm{E}+2$ \\
\hline (10wt. $\% \mathrm{BaTiO}_{3}+15 \mathrm{wt} . \%$ Clay)/ PVC & $1.08 \mathrm{E}+3$ & $2.63 \mathrm{E}+3$ \\
\hline$\left(10\right.$ wt. $\%$ Clay+15wt. $\left.\% \mathrm{Fe}_{2} \mathrm{O}_{3}\right) / \mathrm{PVC}$ & $7.86 \mathrm{E}+2$ & $2.84 \mathrm{E}+2$ \\
\hline$\left(10\right.$ wt. $\%$ Clay+15wt. $\left.\% \mathrm{BaTiO}_{3}\right) / \mathrm{PVC}$ & $1.13 \mathrm{E}+3$ & $2.49 \mathrm{E}+3$ \\
\hline
\end{tabular}

The dielectric strength of the polyetherimide is varies between 28 to $35 \mathrm{kV} / \mathrm{mm}$ but when mixing Polyetherimide with 15wt.\% multi walled carbon nanotubes (MWCNT) with dielectric constant about 300 The dielectric strength of the polymer matrix is improved to $41 \mathrm{kV} / \mathrm{mm}$ [29]. As a while as, this research has been depicted the electric field distribution in power cables with using new PVC nanocomposites material like (10wt.\%Clay+15wt.\% BaTiO3)/ PVC. The dielectric strength of the polymer matrix has been improved than 
use only PVC insulation material in Power Cables. Whatever, the effect of nanoparticles for enhancing electric stress in XLPE insulation material has been studied in some recent refs. [30-32].

\section{CONCULASION}

Type and concentration of nanoparticles which are added to insulation material of power cable have been changed the dielectric constant of insulation material weather effect in changing in self-capacitance of insulator then it is effect on the electric field distribution. Using individual nanocomposite materials and multinanocomposite material instead of pure PVC insulation material decreases and increases the electric stress distribution from $2.14 \%$ to $89.2 \%$ according to type and concentration of nanoparticles. Adding multiple nanoparticles composed of (Clay, $\mathrm{Al}_{2} \mathrm{O}_{3}, \mathrm{Fe}_{2} \mathrm{O}_{3}$ and $\left.\mathrm{BaTiO}_{3}\right)$ that have controlled in the electric field distribution inside power cable insulation. and the electrostatic field distribution inside the voids (Air, water and impurities). The main feature of using multiple nanocomposites insulation is the controlling in multidisciplinary electrical, mechanical and physical properties of the insulation of single-and three-core power cables.

\section{ACKNOWLEDGEMENTS}

The present work was supported by Nanotechnology Research Center at Aswan University that is established by aiding the Science and Technology Development Fund (STDF), Egypt, Grant No: Project ID 505, 2009-2011.

\section{REFERENCES}

[1] H. Elayyan, and M.Abderrazzaq, "Electric Field Computation in Wet Cable Insulation Using Finite Element Approach," IEEE Transactions on Dielectrics and Electrical Insulation., vol. 12, No. 6, pp.1125-1133, December 2005.

[2] S. Patel, S. Chaudhari, and M. Patel, "Analysis of Electric Stress in High Voltage Cables Containing Voids," International Journal of Engineering Research \& Technology (IJERT), vol. 3, Iss. 3, pp.1443-1447, March - 2014.

[3] S. Lachini, A. Gholami, and M. Mirzaie "The Simulation of Electric Field Distribution on Cable under the Presence of Moisture and Air Voids," The 4th International Power Engineering and Optimization Conf. (PEOCO2010), Malaysia,pp.149-153, 2010 .

[4] A. Nosseir, "Calculation of Discharge Inception Voltage Due to the Presence of Voids in Power Cables," IEEE Trans. Electr. Insul, vol. 14, no. 2, April 1979.

[5] S. Avinash, and K. Rajagopala, "Some Aspects of Stress Distribution and Effect of Voids Having Different Gases in MV Power Cables," IOSR Journal of Electrical and Electronics Engineering (IOSR - JEEE), vol. 5, iss. 6, PP 16-22, 2013.

[6] A. Thabet, " Theoretical Analysis for effects of nanoparticles on dielectric characterization of electrical industrial materials,"Electrical Engineering (ELEN) Journal, Springer, vol. 99, iss. 2, pp 487-493, June 2017.

[7] A Thabet, and Y. A. Mubarak, "The Effect of Cost-Fewer Nanoparticles on the Electrical Properties of Polyvinyl Chloride,” Electrical Engineering Journal, Springer, vol. 99, iss. 2, pp. 625-631, June 2017.

[8] A. Thabet, and A.A. Ebn alwaled," Improvement of surface energy properties of PVC nanocomposites for enhancing electrical applications," Journal of the International Measurement Confederation (IMEKO), Elsevier, vol. 110, pp. 78-83, Nov. 2017.

[9] O. Gouda, Y. A. Mobarak, and M. Samir, "A Simulation Model for Calculating the Dielectric properties of NanoComposite Materials and Comprehensive Interphase Approach" 14th International Middle East Power Systems Conference (MEPCON), Cairo University, Egypt, pp. 151-156., Dec. 2010.

[10] K. K. Karkkainen, A. H. Sihvola and K. I. Nikoskinen, "Effective Permittivity of Mixtures: Numerical Validation by the FDTD Method", IEEE Trans. Geoscience Remote Sensing, Vol. 38, pp. 1303-1308, 2000.

[11] M. Todd and F. Shi, "Molecular Basis of the Interphase Dielectric Properties of Microelectronic and Optoelectronic Packaging Materials", IEEE Trans. Components Packaging Techn., Vol. 26, No. 3, pp. 667-672, 2003.

[12] M. Todd and F. Shi, "Characterizing the Interphase Dielectric Constant of Polymer Composite Materials: Effect of Chemical Coupling Agents”, J. Appl. Phys., Vol. 94, pp. 4551-4557, 2003.

[13] A. Thabet, N. Salem, and Essam E. M. Mohamed, "Modern Insulations for Power Cables Using Multi-Nanoparticles Technique," International Journal on Electrical Engineering and Informatics (IJEEI), vol.10, no.2, pp. 271-279, June 2018.

[14] A. Thabet, "Thermal experimental verification on effects of nanoparticles for enhancing electric and dielectric performance of polyvinyl chloride", Journal of the International Measurement Confederation (IMEKO), Vol. 89, pp. 28-33, 2016.

[15] A. Thabet, Y. Mobarak, N. Salem, and A. El-Noby, "Performance Comparison of Selection nanoparticles for insulation of three core belted power cables" International Journal of Electrical and Computer Engineering (IJECE), Vol.10, No.3, pp. 2779-2786, 2020. 
[16] A. Thabet, and N. Salem, "Experimental Progress in Electrical Properties and Dielectric Strength of Polyvinyl Chloride Thin Films Under Thermal Conditions" Transactions on Electrical and Electronic Materials Journal, Vol.21, Issue 2, pp. 165-174, 2020.

[17] A. Thabet, and N. Salem, "Experimental verification on dielectric breakdown strength using individual and multiple nanoparticles in polyvinyl chloride" Transactions on Electrical and Electronic Materials Journal, Vol.21, No.3, pp. 274-282, 2020.

[18] A. Thabet, and N. Salem, "Experimental Investigation on Dielectric Losses and Electric Field Distribution inside Nanocomposites Insulation of Three-Core Belted Power Cables" Advanced Industrial and Engineering Polymer Research, Vol.4, Issue 1, doi.org/10.1016/j.aiepr.2020.11.002.

[19] H. N. O, T. R. Blackburn, B. T. Phung, H. Zhang, and R. H. Khawaja, "Investigation of Electric Field Distribution in Power Cables with Voids," IEEE 8th International Conference on Properties \& applications of Dielectric Materials, pp. 637-640, 2006.

[20] Khanjan N. Jariwala, "Electronic Stress Analysis of High Voltage Cables," International Journal of Research in Engineering and Technology, vol. 3, iss.4, pp. 94-97, Apr-2014.

[21] A. Thabet, Safaa Abdelhady, Abdel-Moamen Mohammed Abdel- Rahim, "Design of Multi-Nanoparticles Technique for Enhancing Magnetic Characterization of Power Transformers Cores,"Advances in Electrical and Electronic Engineering journal, vol. 16, no. 2, June 2016.

[22] Nexans Energy Networks Company, 6-36kV Medium Voltage Underground Power Cables XLPE insulated cables catalogue, march 2010, [online] Available: www.nexans.co.uk.

[23] M Alsharif, P A Wallace, D M Hepburn, and C Zhou, "FEM Modelling of Electric Field and Potential Distributions of MV XLPE Cables Containing Void Defect" COMSOL Conference, Milan, pp. 1-4, 2012.

[24] VEGA Grieshaber KG, List of dielectric constants catalogue, [online] Available: www.vega.com.

[25] A. Thabet, and Y.Mobarak, "Novel Nanocomposite Insulation Materials for The Enhancing Performance of Power Cables," ${ }^{21}$ st International Conference on Electricity Distribution, 6-9 June, Frankfurt, pp. 1 - 4, 2011.

[26] Ahmed Thabet Mohamed, "Design and Investment of High Voltage NanoDielectrics" IGI Global, Publisher of Timely Knowledge, ISBN13: 9781799838296, ISBN10: 1799838293, EISBN13: 9781799838302, DOI: 10.4018/978-1-7998-3829-6, Pages 363, August 2020.

[27] K. Venkata Sahithya, D. Kavitha, Meera Balachandran and Mohan Kumar P, "Polymer Nanocomposite Containing High Permittivity Nanoparticles for Energy Storage Application,” International Journal of Nanotechnology and Applications, vol.11, no.4, pp. 308-318, 2017.

[28] H. A. Illias, Z. H. Lee, A. H. A. Bakar, H. Mokhlis, G. Chen and P. L. Lewin, "Electric field distribution in $132 \mathrm{kV}$ one piece premolded cable joint structures," IEEE International Conference on Condition Monitoring and Diagnosis, Bali, Indonesia, September 2012.

[29] Ilona Pleşa, Petru V. Noţingher, Cristina Stancu, Frank Wiesbrock and Sandra Schlögl, "Polyethylene Nanocomposites for Power Cable Insulations," Polymers, 2019.

[30] D. P.Borthakur and S.Das, "Life Estimation of XLPE Cable Under Electrical and Thermal Stress," International Conference on High Voltage Engineering and Technology (ICHVET), 2019.

[31] C. Kim, P. Jiang, F. Liu, S. Hyon, M. Ri, Y.Yu, and M. Ho, "Investigation on dielectric breakdown behavior of thermally aged cross-linked polyethylene cable insulation," Polymer Testing,2019.

[32] H.M. Wang, S.C. Fang, Z.Z. Meng, P.X. Song, X. Li, M.Z. Zhu, ... B. X. Du "Dielectric Properties of High Voltage XLPE Power Cables Taken from Service," IEEE Conference on Electrical Insulation and Dielectric Phenomena (CEIDP), Richland, WA, USA, USA, 20-23 Oct. 2019.

\section{BIOGRAPHIES OF AUTHORS}

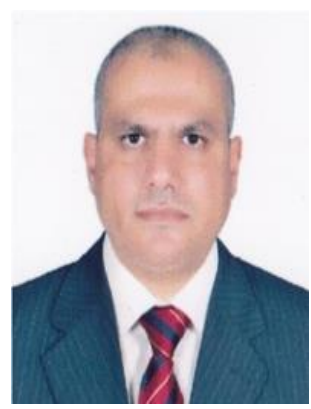

Ahmed THABET was born in Aswan, Egypt in 1974. He received the BSc (HIE) Electrical Engineering degree in 1997, and MSc (HIE) Electrical Engineering degree in 2002 both from High Institute of Energy, Aswan, Egypt. PhD degree had been received in Electrical Engineering in 2006 from El-Minia University, Minia, Egypt. He joined with Electrical Power Engineering Group of Faculty of Energy Engineering in South Valley University as a Demonstrator at July 1999, until; he held Professor position at October 2017 up to date. His research interests lie in the areas of analysis and developing electrical engineering models and applications, investigating novel nanotechnology materials via addition nano-scale particles and additives for usage in industrial branch, electromagnetic materials, electroluminescence and the relationship with electrical and thermal ageing of industrial polymers. A lot of mobility's has investigated for supporting his research experience in UK, Finland, Italy, and USA ...etc. On 2009, he had been a Principle Investigator of a funded project from Science and Technology Development Fund "STDF" for developing industrial materials of ac and dc applications by nano-technology techniques. He has been established first Nano-Technology Research Centre in the Upper Egypt. He has high quality publications which have been published and under published in cited international journals and conferences. On 2018, he has been held a full professor position in Engineering of College at Qassim University in Kingdom of Saudi Arabia up to date.

IJEEI, Vol. 9, No. 1, March 2021: $8-21$ 


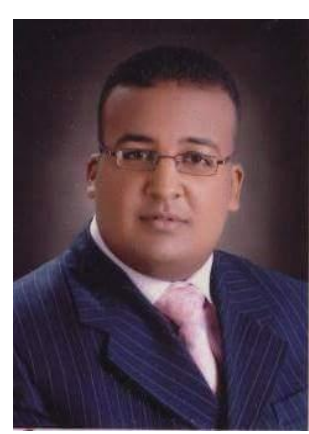

Mohamed Fouad was born in Qena, Egypt in 1986 and received the BSc degree in electrical engineering from Faculty of Eenerg Engineering, Aswan University, Egypt in 2008.he received the Diploma degree in electrical engineering from Faculty of Engineering Qena, south vally University, Egypt in 2013. he is working as Operation Manager in Nag Hammadi Hydro Power Plant Since 2009 up to date. he is M.Sc. Student in electrical engineering in Faculty of Energy Engineering, Aswan University, Egypt, from 2014.

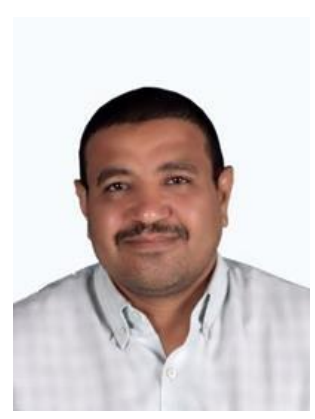

Abdel-Moamen M. A received B.Sc. Degree and M.Sc. Degree in Electrical Engineering from Assuit University, Egypt, in 1991 and 1998, respectively. He joined Aswan Faculty of Energy Engineering as an Assistant Lecturer, Egypt in 1993. He obtained his Ph.D. Degree in Electrical Engineering from Indian Institute of Technology (IIT), Roorkee, India, in 2004. He is currently working as assistant Professor at the department of Electrical Engineering, Faculty of Engineering. South Valley University, Qena, Egypt. His field of interest is Power System Privatization, Restructuring and Deregulation, Application of Power Electronics to Power Systems, Optimal Power Flow Incorporating FACTS Devices.

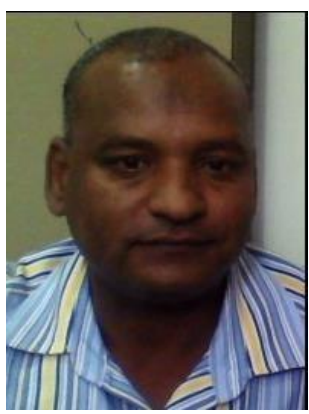

A. El-Nobi was born in Egypt. He received his B.Sc. and M.Sc. degrees in Electrical Engineering from South Valley University, Aswan, Egypt, in 1997 and 2006 respectively. He joined Electrical Engineering Department, High Institute of Energy, South Valley University as a Demonstrator, as an Assistant Lecturer, during the periods of 1999-2005, PhD degree had been received in Electrical Engineering in 2010 from El-Minia University, Minia, Egypt. 